\title{
Water Areas of Kiev: Losses, Gains and Ways of Revival
}

\author{
Nikolai Demin ${ }^{1}$, Olga Mykhailyk ${ }^{2}$ \\ ${ }^{1}$ Department of Urban Construction, Faculty of Urbanism and Spatial Planning, Kiev National University of Construction and Architecture, \\ Kiev, Ukraine \\ ${ }^{2}$ State Enterprise "NIPIgradostroitelstva", Kiev, Ukraine
}

Email address:

deminmaster@gmail.com (N. Demin), mykhailykolga@gmail.com (O. Mykhailyk)

\section{To cite this article:}

Nikolai Demin, Olga Mykhailyk. Water Areas of Kiev: Losses, Gains and Ways of Revival. Urban and Regional Planning. Vol. 5, No. 4, 2020, pp. 109-113. doi: 10.11648/j.urp.20200504.12

Received: November 5, 2020; Accepted: November 20, 2020; Published: November 27, 2020

\begin{abstract}
The article is devoted to one of the most important issues of urban planning - the coexistence of water bodies and the city. Vulnerability of natural waters in the urban environment is compared to the circulatory system of the human body. For illustrative purpose, the great Leonardo da Vinci, who initiated regional redevelopment using both river resources and human activities, is cited. The status of river ecosystems of the city of Kiev is considered retrospectively. The Dnieper River is the main waterway of Kiev. It is this great European river that gave birth to one of the world's most beautiful cities - Kiev, the capital of Ukraine. The River Dnieper plays an important role in the modern life of the city as well as it did in the ancient times. The article highlights and suggests ways to elaborate environmental problems of the Dnieper River today. The article describes numerous small rivers of Kiev and artificially created lakes of the Opechen system which along with other water areas form a rich water network of Kiev. It emphasizes the contribution of Kiev builders in the creation of new housing estates and the Kiev Venice canal by the method of hydronium which was later introduced in world practice. Most regrettably, the river harbor on the historic river Pochayna and the drinking water source were lost for the people of Kiev in the course of time. The article shows the interrelation of modern factors of anthropogenic load on the water area of Kiev as well as the coexistence of the river and the costal territories. Actions are proposed to preserve ecosystems in accord with the Water Code of Ukraine. Finally, measures are put forward to revival and preservation of reservoirs and their coastal areas. Professional planning of river areas and the establishment of restrictive green lines will help preserve the natural component of the urban body of Kiev.
\end{abstract}

Keywords: Circulatory System of the City, River Dnieper, Small Rivers of Kiev, Lakes of the Opechen System, Kiev Venice, Ecological System of the River

\section{Introduction}

Since ancient times, people have perceived cities as a living organism -there is a time of its coming to life, then the period growth, development, prosperity and, finally, decay. Figure 1 depicts the principle of representation of the «body» and «city» in the Middle Ages, when the artificial depicts the natural - the idea of the «state»is realized through the idea of the «human body». This congruence in the Renaissance was represented by a certain set of codes: the king - as the head (or in the depiction of the heart), the population - as the body, the law was compared to the nervous system, the army - with the hands, trade - with the feet, often - with the stomach, and so on The same analogy was applied to cities (rather - «ideal» cities). The location of its main buildings and structures compared to the organs of a human body is as follows: the castle is the head, the market - the lunds, the town hall - the stomach, the city gates are the limbs (Figure. 1).

The emergence of towns is facilitated by rivers, which becom the main urban vector of development of the city and its «circulatory system". The connection between the city and the river is one of the most important issues in urban planning. Figure 2 illustrates Leonardo da Vinci's graphical reflection about Florence's city plan along the Arno River, which flows in the middle of the city. Leonardo's conceived Florence as an «idea city» with the navigable Arno River. The construction of an $80 \mathrm{~km}$ long canal was to ensure the delivery of goods to the houses; the water level in the canal was supposed be regulated by a system of locks. This was the inception of the idea of regional redevelopment using river resources and human activites [1]. 


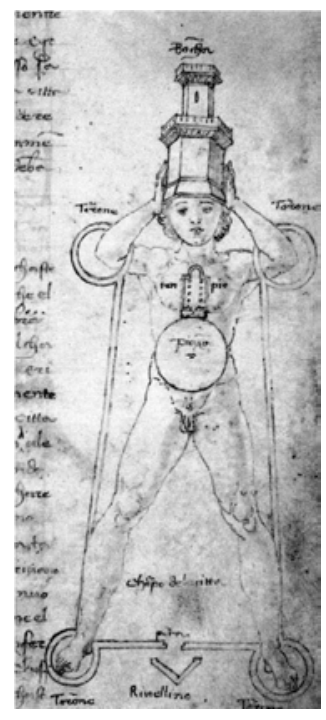

Figure 1. Dee Giorgio Martini. Body is a city of Florence.

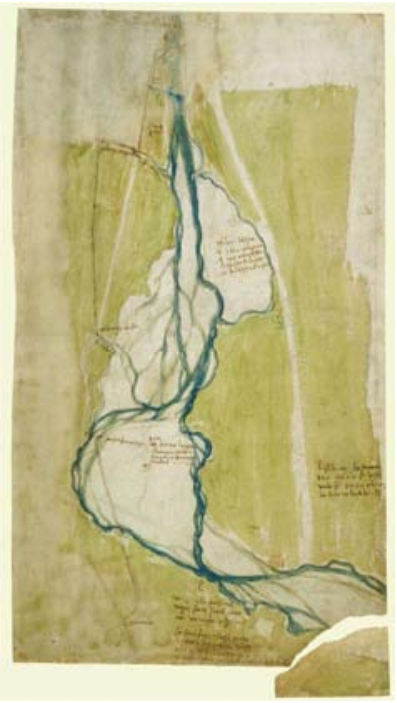

Figure 2. Leonardo da Vinci. The river Arna.

\section{Water Network of Kiev}

\subsection{Dnieper - One of the Major Rivers of Europe}

One of the major rivers in Europe - Dnieper with its picturesque banks and enabled the development of Kiev - the heart of Ukraine. Kiev's territory plays a key role in the widely spread network of the river ways in the upper part of the Dnieper basin. Kiev's location at the intersection of river routes «from the Viking to the Greeks» has for a long while contributed to the lively trade between the residents of the Baltic countries and Black Sea coastland as well as Western and Eastern Europe. One of the main sources of income of the ancient Kyivans was fishing. The most profitable fishing fields belonged to the magistrate and monasteries - KyivPechersk, Bratsk, Pustynno-Nikolsky, and other. The establishment in 1858 in Kiev of the «Shipping Society at Dnieper» promoted economic development of the city [2]. The Dnieper has always been a powerful hydrographic «ridge» not only for Kiev, but for the whole of Ukraine.

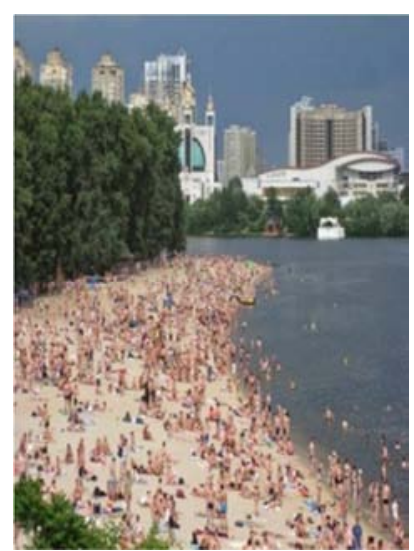

Figure 3. The golden sand of Dnieper's beach.

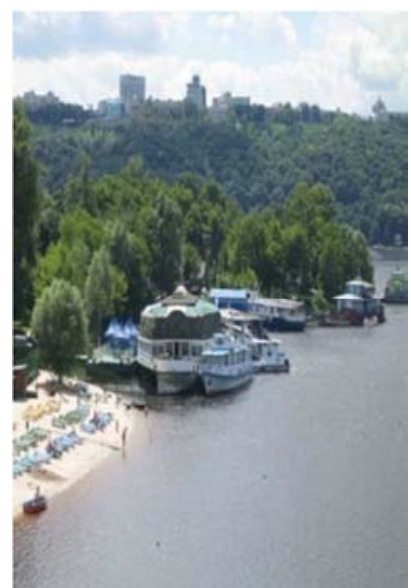

Figure 4. River station.



Figure 5. The Dnieper River in Kiev

The modern Dnieper, with its numerous tributaries and 36 islands, is significantly important for Kiev - the Dnieper and the mouth of the Desna are the main source of water supply for the city; Dnieper waters fill hundreds of thousands of hectares of arid areas, the might of the Dnieper enables to generate large amounts of electricity, ets. The Dnieper remains an important transport artery of the nation. Industrial enterprises were removed from the banks of the Dnieper and a recreational zone was created for Kyivites (Figures 3-5).

In Kiev's urban environment this large river continues to 
undergo changes: the main channel is diverted to the historic right bank of the city, in winter the ice cover of the river has decreased considerably, in the southern city border there is an increase in concentrations of biogenic and organic substances. In recent decades, the construction of a cascade of reservoirs in the Dnieper basin resulted in climate changes - the average annual air temperature has increased by $1.5^{\circ} \mathrm{C}$, decrease in rainfall, wind speed, coastal areas covered with natural meadows and forests has been observed. Fortunately, the volume of the river is not showing any sign of decreasing, while and the runoff coefficient has increased slightly.

In addition to the Dnieper, Kiev's water network has 426 objects, such as:

110 small rivers with a total length of $86.26 \mathrm{~km}$;

230 water chanels with a total length of $62,37 \mathrm{~km}$;

32 tributaries with a total length of $4,5 \mathrm{~km}$;

436 streams with a total length of $50.09 \mathrm{~km}$;

534 springs;

6141 lake, with the total area of the water mirror - 996.4 hectares, which mainly belong to the Dnieper floodplain;

7103 ponds, the total area of water-surface - 321.61 hectares;

843 artificial reservoirs, the total area of water-surface 674.13 hectares [3].

\subsection{Small Rivers of Kiev}

The small rivers the Vita, the Hlybochytsia, the Darnytsia, the Kiyanka, the Lybid, the Nyvka, the Pochayna, the Syrets, the Khreschatyk, the Yurkovytsia have played a vital role in the history of Kiev. Intensive urbanization has led to their degradation - today the small rivers of Kiev are full of sewage catchment, they are shallow and polluted, seldom freeze in winter. Most of these small rivers flow in concrete tunnels and gutters. It will be appropriate if some the rivers are considered separately.

The Lybid was first mentioned in 968 as a navigable river that flowed from the northwest of the city to the southeast up to 3-4 $\mathrm{km}$ from the Dnieper. It had a wide swamp and constituted the natural border of the city [4]. A dam was built on the Lybid to prevent the advance Turkish cavalry during the Russian-Turkish War. The tributaries of the Lybid were the Khreshchatyk and the Skomorokh, which flowed into the Lybid near the Victory Square. Presently the current state of the Lybid is characterized by intersection of numberous bridges and pipelines (Figures 6-8). Much of the river flows underground and received sewage; the banks of the Lybid River are covered with concrete, and partially with rubble stones. The only part of the Lybid with natural riverbed is in front of Stolychny Highway. In this part of the river fish is found. The banks of river Lybid are covered with bushes and trees. At the water intake of the river there are important like the botanical garden, the zoo, Vidradnensky park, i.e. at the point where the river originates (photo 4). At the point of water intake one can see ancient oaks, some of them more than 200 years old.

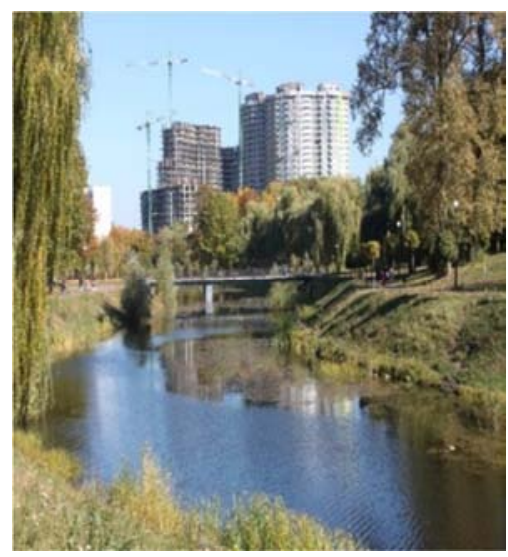

Figure 6. Vidradnensky park.

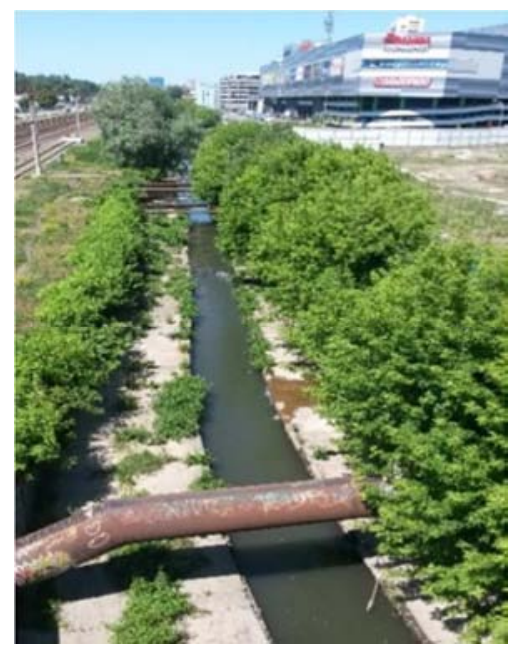

Figure 7. Urbanized Lybid.

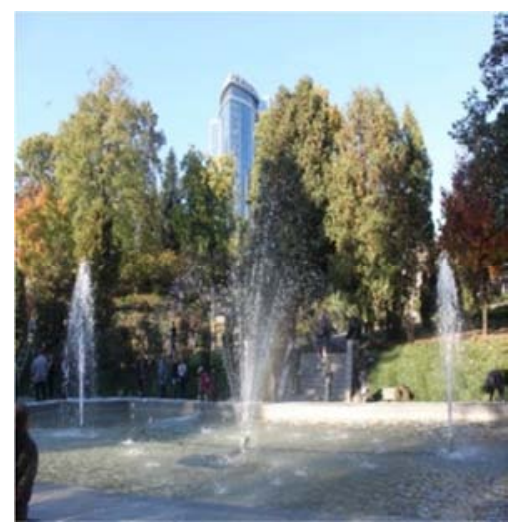

Figure 8. Botanical Garden.

More than 20 ponds were constructed on the small river Nyvka. The most picturesque is the pond on the western border of Kiev near the Kyiv - Zhytomyr highway where there is a stretch of pine forests. Vacationers like to do fishing here, as crucian carp (gold fish), perch, black perch, ets. are found in the ponds.

In the past, the Syrets River was instrumental in the economic of Kiev. On the map of Kiev of 1695 we find 9 mills, and clay (used for the production of bricks) mines in the river valley. Now this small river is locked in a collector 
and flows into one of the lakes of the Opechen system.

Ancient Kiev once had a first-class river harbor on the Pochayna River, which flowed along the Obolon and Podil and flowed into the Dnieper near the Post Square. The tributary of the Pochayna was the river Hlybochytsia, which flowed along the Podil, and into which the stream Kiyanka flowed at the foot of the Castle Hill [5]. The chronicle river Pochayna, where Volodymyr baptized Kyivans in the 10th century, is waiting for its revival.

\subsection{Lakes of the Opezhen Sistem}

The Pochayna's «descendants» are the lakes of the Opechen system - Bogatyrske, Verbne, Yordanske, Kyrylivske, Luhove, Minske, Opechen, Redchyne, which surround Obolon from the west and south. In 1970-1973 a chain of artificial lakes was created in in the river floodplain as a sand quarrying for hydraulicking of the industrial zone and the residential area. Water area is used for recreational purposes, for the supply of drinking water, for economic and industrial needs in the city. In Lake Verbne (Figures 9-10) there is a fern, floating salvinia, of which there is a mention in the Red Book of Ukraine. In it there is also a mention of more than 20 species of fresh water fish. In 1944 according to the Kiev City council decree no. 14 of 17.02 .1994 the lake was declared an ichtyological and botanical reserve [6].

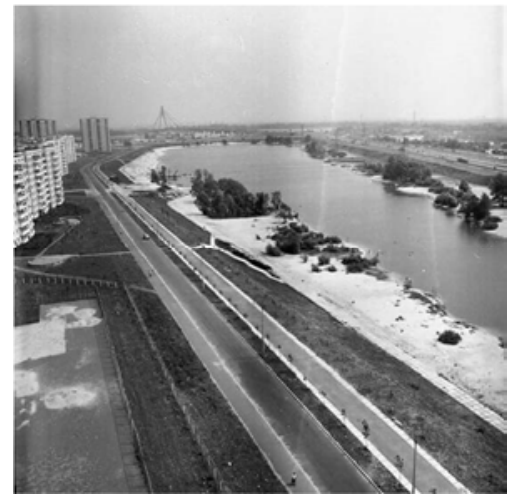

Figure 9. Lake Verbne in the 70's.

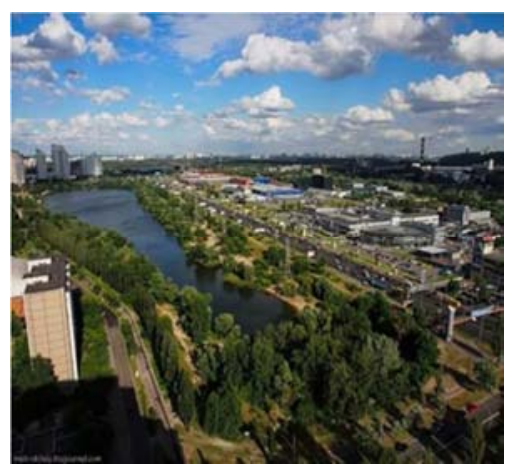

Figure 10. Lake Verbne today.

On the western and northern banks of Lake Redkine (Ministerka) beaches have been constructed, because of its clear water and the healing blue hour clay, which is found at the bottom of the lake. This place is an attraction for the vacationers.

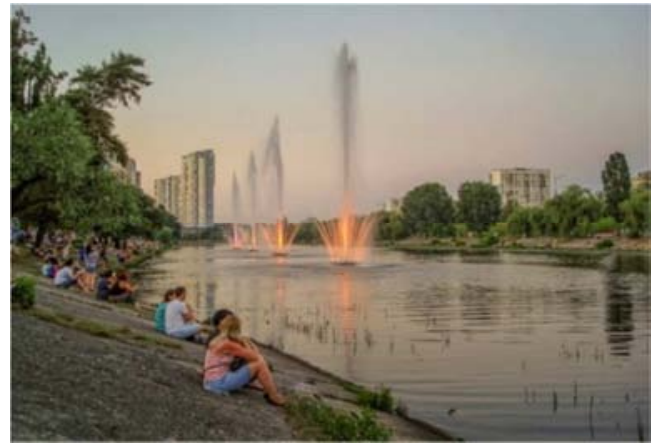

Figure 11. Waterfalls of Kiev.

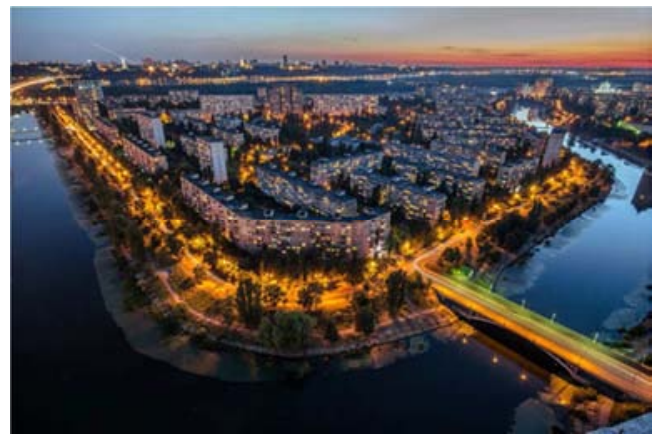

Figure 12. The canal Kiev Venice.

The development of Kiev in the period of 60-70 years of the XX century was marked by the birth of new residential areas on the Left bank of the Dnieper - Bereznyaki and Rusanovka, which are divided by the bypass canal Kiev Venice (Figures 11-12). For the first time in the world practice, Kiev's developers found a hydraulicking method in order to use nonarable floodplains for housing construction. The Rusanivska former riverbed and specially constructed channel became quarries for the hydraulicking [7].

\section{Ways to Revive the Waters of Kiev}

Kiev continues to develop. Its «circulatory system»- rivers, ponds, canals - help the city maintain its health and beauty. Modern «health hazards» for the water reservoirs of Kiev are industry, vehicles, landfills trash dumps, and construction sites in coastal areas. Hence, as a result of intensive engineering and construction works, the norms of the drainage system have been severely violated, which has led to an increase in certain parts of the city groundwater level; and as a consequence the area of flooded areas in Kiev has increased to over 7,000 hectares. The problem of providing the population in particular with clean drinking water is extremely acute. The revers Dnieper, Dniester, Seversky Donets, Southern Bug, Tisza are the main water resources of Ukraine. The specific supply of river runoff in Ukraine is about 1 thousand $\mathrm{m}^{3}$ per person per year, which in 2.5 times lower than in Germany and Sweden, 3.5 times lower than in France and 5 times lower than in England [8].

River and its coastal areas are an interconnected since they 
both constitute the ecological system. Hence the degradation of the river directly affects the deterioration of its coastal lands. The ecological condition of the water lands depends on the condition of the coastal territory, preservation of water protection zones and improvement of coastal protection strips. Measures taken to preserve and improve the existing condition of Kiev's water areas should revive and protect coastal landscapes - valuable urban natural and recreational areas.

The Water Code of Ukraine defines the boundaries of coastal protection zones: for small rivers, streams and creeks, as well as ponds whose area is less than 3 hectares, they constitute $25 \mathrm{~m}$; for medium rivers, water reservoirs on them, as well as ponds with an area more than 3 hectares $-50 \mathrm{~m}$; for large rivers, water reservoirs and lakes - $100 \mathrm{~m}$ [9].

Numbers research articles have highlighted the fact that to establish protective coastal belts of same width along different geological structure, hydrological and hydro biological regime of the coastal areas of the reservoir is not rational [10]. The structure of river valleys is characterized by a multitude of landscape features, geological, hydrological and ecological conditions, the state of vegetation and the degree of anthropogenic development and transformation. The size of the coastal protection belts should take into account the vertical structure of the river valley and the characteristics of the river - large for the headwaters and the upper reaches of the river as these river areas are most vulnerable [11].

The following proposals have been made to protect water objects and Kiev's coastal areas:

1 amendments to the Project «Coastal protective belts of Kiev and water objects» in accordance with the topographic survey and the current state of water objects of the city;

2 continuation of work on shore improvement, cleaning of reservoirs ( 842 hectares) and riverbeds $(28 \mathrm{~km})$ from siltation, overgrowing, littering [12].

\section{Conclusions}

The implementation of water protection measures is a multi-faceted problem. To tackle this problem systemic approach is needed. Determining the boundaries of the coastal zone and taking into account the influence of the river, is subject to the general principles of functional zoning and regional and architectural planning. Professional planning of river-side areas will enable balanced and effective development, and also preservation of water areas [13]. The establishment of boundary green lines will help preserve the natural fabric of the urbanized body of Kiev [14]. «And although man's genius is capable of making phenomenal inventions, he will never be able to invent anything more beautiful and simple than what Nature has created because there is nothing imperfect and superfluous in its inventions», - wrote the great Leonardo [15]. Appreciate, cherish, learn from nature, live in harmony with the environment should be a priority concept in all the spheres of human activity. And, most importantly, this holds true for modern urban planning.

\section{References}

[1] Lecture from the course Urbanism: a modern city.

[2] History of Kiev/ Editor by Kondufor Y. - K.: Naukova Dumka, 1982. -463. p. 125.

[3] Internet view of water resources of Kiev.

[4] Kyrylo Stepanets. Small rivers of Kiev and their researchers. K.: Sidorenko V. B (2015). - 104 p. 24.

[5] Alla Pleshkanovska. Ages and cities. - K.: Logos, 2019.- 264 p. 120.

[6] Arrangement of water protection zones of urban reservoirs on the basis of ecological assessmenr of water quality / Editer by Panasyuk I. - Kiev, 2016. - 94 p. - il. 26 (table 17, figure 15). p. $50-51$

[7] Kirkevich V. G. My city is KIEV. - K: Business - Logika, 2009. - 474. p. 408.

[8] Internet view of water resources of Ukraine

[9] Water Code of Ukraine (1995), Voice of Ukraine 20. 07. N 133 , p. $4.47-51$

[10] Yatsik A. V. Water management ecology: 4 t, 7 c. - K.: Geneza, 2003-2004. - 306. p. 20.

[11] Richard Florida. The new urban crisis. How our cities are increasing inequality, deepening segregation, and failing the middle class - and What we can do about it. (2017). Basic Books. New York.

[12] Nikolai Demin. (2018). Town-planning methods of revitalization of coastal areas of rivers. Modern problems of architecture and urban planning. Scientific and technical collection. Kiev National University of Construction and Architecture, 52, 454 p. 203.

[13] Acupuncture Urbana by Jaime Lerner (2017). - Lviv: Old Lion Publishing House. - 160 p. 24.

[14] Olga Mykhailyk. (2020). Features of the protection of coastal areas. Problems of urban environment development. Scientific and technical collection, 2 (25), 265 p. 113.

[15] Oksana Ochkurova. Stories through faces and events. Geniuses who changed the world. - Kharkov: Folio, 2010. 510 p. 106. 